\title{
THE NEGRO AND AGRICULTURAL DEVELOPMENT
}

\author{
By Alfred Holt Stone,
}

Author of "Studies in the American Race Problem," etc., Dunleith, Miss.

To say that Negro labor has been the most important single primary factor in the development of southern agricultural resources, is to restate a very old and commonly accepted historical fact. To say that such labor was absolutely essential to southern development, is to repeat a statement whose age does not entitle it to exemption from the category of historical fallacies. To regard the further development of southern agriculture as dependent upon Negro labor, is to ignore both the history and the present status of an important branch of American industry.

The agriculture of the southern colonies of Great Britain differed essentially from that of the colonies along the upper Atlantic seaboard. The latter may be said to have been concerned mainly with the production of food supplies. The chief end of the former was the creating of revenue. It was the difference between an agriculture devoted to the production of a great staple crop, intended for foreign export, jealously regarded by the parent government as one of the mainstays of its commercial and maritime position among the trading nations of the world, and an agriculture devoted to the production of commodities for domestic consumption. In the one case, agriculture became, naturally and inevitably, the chief business of the section or country engaged in it; in the other, just as naturally, it was subordinate to some other form of industry.

The first essential in any staple agricultural system, is a combination of soil and climate favorable to the production of a commodity which finds a ready exchange for money in the markets of the world, and which, in either a raw or partly manufactured state, is susceptible of transportation through long distances. Whatever the final course of development followed by any country possessing these natural features, its original foundation will be staple agriculture. This is subject only to the modifying influence of the presence of one of the precious metals. The second essen- 
tial to the development of a system of agriculture,-assuming of course the existence in some form of the necessary capital,--is a supply of labor adapted to the work to be performed. The crux of the purely economic argument for and against slavery, as a southern industrial system, was in this question of the supply and adaptability of labor for and to southern staple agriculture. The controversy was never settled, and it is as inviting a field for economic discustion to-day as it was before I860. The economic justification for slavery, in the early period of the institution, was founded upon two contentions; first, that no other race than the Negro was capable of doing the necessary work under the climatic conditions of the staple producing colonies; second, that the only means whereby a supply of Negro labor could be had was through some system involving purchase and control.

If Negro labor was the only labor which could be employed at the outset, in establishing the agricultural industry of the British West Indies, - that is, if the first of the above propositions is correct,- - then slavery was a necessary incident to such agriculture, and the second proposition is also established. There has never been a voluntary emigration of Negroes from Africa. But the history of some of the West Indies, notably San Domingo and the Barbadoes, suggests that white labor might have been employed even in the laborious work of sugar production. That the small white holdings in Barbadoes were absorbed into larger estates, and the free white labor supplanted by Negro slave labor, also illustrates the fallacy of an old economic axiom dear to the hearts of certain anti-slavery economists,-namely, that slave labor could not compete with free. The truth is that at one period or another white labor played an important part in the agricultural development of practically all of the southern and West Indian colonies. At the same time, the evidence leads strongly to the conclusion that in most of those colonies the climate and other physical conditions were such during their periods of original settlement that the Negro was better fitted than the white man for productive field labor on an extensive scale. We shall probably state the case correctly if we say that owing to his adaptability to the work required under the given conditions of soil and climate, and the power of control incident to his status as a slave, the labor of the Negro was preferred to that of the white man by the early producers of the great tropical or semi-tropical 
agricultural commodities. After all, however, this was only a preference.

The course of this first great American industry would have been different, had its dependence been upon white labor alone, and its development would have been slower, but this is the most we can say. Sugar would still have gone from the West Indies and Brazil, and indigo and rice from Carolina, and tobacco from Virginia, if not a Negro had ever set foot on American soil,- -and the South would still supply the world with cotton. Whatever the opinion of those most closely in contact with Negro labor,-who in the main know little or nothing of any other kind,-it is none the less a fact that white labor can accommodate itself to any work which can be performed by the Negro, whether it be the draining of Mississippi lowlands in 1860 , or the digging of the Panama Canal a half century later. Yet we must begin a consideration of the future of southern agriculture with some millions of Negroes already on the ground. No matter what might have been the history of southern agricultural development, the fact remains that in it the labor of the Negro has played a dominant part. In speculating upon what his part is to be in the future, however, we should not follow the false lead of assuming such further development to be wholly dependent upon him.

The agricultural industry of the South is still the growing of staple crops. Among these crops cotton still holds the dominant position which it assumed shortly after the invention of the gin. The other staples are tobacco, rice and sugar. Indigo died with the Revolution. Cotton owes its supremacy largely to the fact that it can be grown over a greater range of territory than either of the others. The other three can be grown to some extent outside the areas now devoted to them, but, with the possible exception of rice, they give no promise of even partially successful competition with cotton. A future permanent increase in the output of southern tobacco is probably more dependent upon improved methods of cultivation than upon any considerable increase in acreage. Nor is there much probability of a permanent extension of the cane area. It remains to be seen if the recent spread of rice growing, in Louisiana and into Texas and Arkansas, is stable or temporary. In so far as the Negro's part in the future of southern agriculture is concerned, whatever it is destined to be, it is linked with the future of cotton. 
Cotton growing as an industry has suffered the vicissitudes which seem the common lot of the semi-tropical staples. It has never been on a sound basis, and is not to-day. There have been too many middlemen, and too many who, while outside the actual business of growing the staple, have largely controlled the policy and actions of the real producer. There has been something inherently vicious in the whole system and methods, from an economic standpoint,--from the beginning to the present time. There has always been something peculiarly attractive about the hazards of the business when conducted on a large scale, and, like sugar in the earlier days, it has drawn to it men who were better fitted for other fields, and it has wrecked more fortunes than it has made. When the gentleman adventurer from England went out to the Barbadoes, before the end of the seventeenth century, it was with the hope and expectation of reaping a rich harvest from the sugar fields, and soon returning home. He had no capital, but that was easily found by the factor and merchant in London. He had no labor, but his merchant easily arranged that with the agents of the Royal African Company. His equipment and land, like his labor, he bought on credit. If he were successful during the first year or two, he repaid his obligations to the factor, in whole or in part, but always, almost without exception, he also at once borrowed again, and on a larger scale, and increased his operations. He bought more land and machinery, increased the number of his slaves, put his domestic affairs upon a more lavish scale,-and always by a liberal use of his credit. Another crop either enabled him to meet his obligations and still further increase his operations, or it left him stranded. Sometimes he returned in wealth, but oftener he ground out his life in an endless effort to make annual interest for his factor, and bequeathed a mortgaged estate, to be foreclosed when there was no one left either willing or able to carry the load.

No one acquainted with the economic history of the British West Indies will say that this picture is overdrawn. Even the most superficial reader must realize that behind such methods there must have been some extraordinary inducement to the persons who furnished the capital. It is here that we touch the most vicious feature of the entire so-called plantation system of agriculture. The factor not only demanded a high rate of interest on the money furnished and on old debts carried, but a fundamental feature of 
the business was the payment of both principal and interest in kind. The factor's profit was by no means confined to the interest charged on his loans. In large part it consisted of the commissions which he charged both on the purchases made for his customer and on the commodities sold for him. The basis of credit was the quantity of sugar the planter undertook to produce,-all of which had to be consigned to the factor. There was thus not only no incentive to even a crude form of agricultural diversification in the sugar colonies, but any such tendency was strangled by the demand for more sugar, and the consequent devotion of every available acre of ground to an effort to supply the demand. No country, no region, however fertile, can forever stand the outward drainage of its earnings in the shape of interest payments and purchases of things which should be grown within its borders. Inevitable bankruptcy is its final portion,--and this came to the richest as well as the poorest of the British West Indies.

The so-called plantation system was in fact merely borrowed, or transferred, from the British islands to the British colonies on the continent. The history of the Barbadian and Jamaican sugar planter became in large measure the history of the Virginia tobacco planter and the South Carolina grower of indigo. The Revolutionary War wiped out mortgages held in London and Liverpool, but the system remained. When rice and cotton became the chief business of the planters of South Carolina and Georgia, the merchants and factors of Charleston and Savannah succeeded to the controlling positions so long held by their predecessors abroad. Instead of sugar, the basis of credit became the number of bags of rice or bales of cotton which the planter could produce, and the vicious circle of a steady increase of credits, debts, interest, land, slaves and crops repeated itself over and over again. It is not meant to convey the idea that there were no escapes from this routine of labor and debt. In the aggregate a number of planters became independent, but the description holds for the great majority. There is no more pathetically untrue picture in fiction than that of the "typical antebellum southern planter," rolling in wealth and living a life of luxurious idleness. As a class, they were the pioneer captains of industry in America, and, in the main, they worked hard, lived on credit and died in debt. The people who reaped most from the system were the merchants and factors who supplied the 
planter with capital and handled the product of his toil, they, and the cotton manufacturers of England,-Old and New.

What has all this to do with the Negro and the agricultural development of the South? The Negro furnishes the connecting link between the past and present of southern agriculture, and he is to play an important part for either good or evil in its future. Had the foundation stone of antebellum southern agriculture been white labor, instead of Negro, the increase of cultivated acreage would have been slower, and the production correspondingly less, but the process of growth would have been sound at the core. Even as it was, there were thousands of small white farmers scattered throughout the South. Without Negro labor, the number of these would have been many times greater. Undoubtedly there would have developed some form of plantation system, but it would have been based upon free white labor, and would have served as a great training school for the production of small farmers.

The Civil War did not destroy the old plantation system. It merely altered the legal status of one of its elements. The Negro in the mass remained economically untouched by the gift of freedom, in so far as any free agency of his own was concerned. Where before, his labor had been bought with his body, now it was his labor alone which came to be trafficked in. The latter was a cheaper transaction than the former, and required less capital. It therefore was engaged in by a greater number of people. Formerly, a high order of intelligence was required to handle successfully a plantation on a large scale, involving as it did the care of the physical well being of its labor, as well as the financing of its operations. Now, the main requirement came to be a small line of credit with a local merchant, and the ability to get together enough Negroes to make a crop for a single year. The best test of success in "making money out of Negroes" ceased to be the capacity to keep down sickness among them, to feed and clothe them properly, to keep them contented even though not free, to work them to the best advantage, having always in view the fact that life was the only limit to their tenure of service. It came to be, instead, the ability to secure their labor at the lowest price, to give them the least for the most work, to keep them satisfied, not by a full stomach, but by the cajolery of promises never intended to be kept, and the unction of words which an antebellum planter would have scorned to utter. Booker Washington has 
repeated over and over again the phrase that before the war the Negro was "worked," but that now he has learned to work himself. The truth is that the Negro has been "worked," as the word is used in the vernacular of the street, to a vastly greater extent since he has been free than ever he was as a slave. Whether it is to be attributed to racial traits and deficiencies, or to a temporary handicap which time will remove, the fact remains that whether as a plantation laborer under modern conditions, or as a tenant securing his yearly supplies from a merchant, the Negro places a tremendous premium upon dishonest practices, and offers to cupidity a most alluring field.

The Negro's part in the future of southern agriculture is problematical. The present method of growing cotton is roughly divisible into three systems. In the first, the land is operated in considerable tracts, varying in size from a few hundred acres to several thousand. Here the labor is almost wholly Negro, working either for.wages, or as renters, or for a share of the crop. In the second, the land is owned by a white man who rents it outright to tenants, and has nothing to do with its operation himself. Here the tenants may be either white or colored,- -varying according to geographical location. In the third class we have the small farmer, who owns and tills his land. The first of these is the true plantation system, as it exists to-day. Its mainstay is the Negro, and without him it would not last a generation,- - possibly not a decade. If the South were filled with white labor, the large plantation would be broken up into smaller tracts, for such labor could not be exploited sufficiently to make the maintenance of large properties more than spasmodically profitable. Such as might remain, would have to be operated on a basis of wages. As there is no likelihood of an influx of white immigration to the South, the question remains one of speculating upon the length of time the plantation system, based upon Negro labor, can be maintained. Under this system the Negro's part in southern agricultural development will remain merely the part played by any labor, working under supervision in any line of industry. Where another furnishes the capital, the brains, and the direction, the part played by labor is no more than that of a tool or a machine. The only active, positive part possible for the Negro must be either as an independent renter, gradually emerging into the landowning class, or as a landowner himself. 
It is only here that his economic status is really higher than that of a day laborer; only here that he has either initiative or control; only here that he becomes an independent economic force.

The Negro has it in his own hands to play either an active or a passive part in the upbuilding of the section in which he lives, which is still primarily an agricultural region. In so far as that section has attempted to depart from the great staples, and turned to other branches of agriculture, save in rare instances it has been exclusively the work of the white man. Of the staple crops, it is only in cotton that the Negro has made any substantial progress. Here, with all our statistical labors, when we come to measure his advance, we find ourselves floundering in a tangle of figures which may mean much or nothing,-and which have to be explained and interpreted and laboriously handled before they mean anything at all. We do not know to-day, nor does any census tell us, how many independent Negro renters we have in the South, as distinguished from those nominally returned as "renters," but whose economic status is really no higher than that of a laborer at a daily wage. We do not know, even approximately, what part of the American cotton crop, at the end of any decade, was the result of Negro labor,-nor whether his part in its production is increasing or is on the decline.

Rather than bring these reflections to an end with an idle speculation about the future, I prefer to conclude them with the hope that the census soon to be taken will throw more real light upon the economic status of the American Negro than has been given us by any previous investigation. If it does, it will place under lasting obligations every student of vital American questions. 